\title{
Transrectal Ultrasonography Guided Biopsy
}

National Cancer Institute

\section{Source}

National Cancer Institute. Transrectal Ultrasonography Guided Biopsy. NCI Thesaurus.

Code C143148.

A procedure that uses transrectal ultrasound to image the prostate and guide the placement of a biopsy needles to obtain a tissue sample. 